\title{
Pecuniary and Non-Pecuniary Aspects of Self-Employment Survival
}

\author{
Yannis Georgellis", John Sessions ${ }^{* *}$, and Nikolaos Tsitsianis ${ }^{* * *}$ \\ * Department of Economics and Finance \\ Brunel University \\ Uxbridge \\ Middlesex UB8 3PU \\ England \\ **Department of Economics \\ University of Bath \\ Bath, BA2 7AY \\ England \\ *** Department of Economics \\ University of Hertfordshire \\ Hatfield \\ Hertfordshire AL10 9AB \\ England
}

\begin{abstract}
We examine the factors that determine self-employment duration in Britain, paying particular attention to self-reported job satisfaction variables and non-pecuniary aspects of self-employment. Based on spell data from the British Household Panel Study, we estimate single-risk and competing-risks hazard models, separately for males and females. Our results show that job satisfaction is indeed a strong predictor of self-employment exit, even after controlling for standard economic and demographic variables. When five domain job satisfaction measures are used, we find that pay, job security and initiative are the three aspects of self-employment most valued by the self-employed themselves. Gender differences regarding the determinants of self-employment survival and exit destination states are also evident.
\end{abstract}

Keywords: Self-employment, Survival, Job Satisfaction

JEL Classification: J23, J28, J60

Word Count: 5844 


\section{Introduction}

Compared to the plethora of studies examining self-employment entry, relatively few studies examine the determinants of self-employment survival and exit. Noteworthy recent examples of empirical studies focusing exclusively on self-employment survival include Johansson (2001) and Taylor (1999). Johansson (2001) uses Finnish longitudinal data and finds that the young, the more educated, and those with previous unemployment experience face a higher risk of exiting selfemployment. Based on data from the British Household Panel Survey (BHPS), Taylor (1999) finds that approximately 40 per cent of self-employment ventures in Britain that started in 1991 did not survive their first year in business. Interestingly, a substantial proportion of self-employment spells is not terminated through bankruptcy but rather through moves to alternative employment. Taylor also highlights the importance of previous unemployment experience, whether individuals quit the previous job, and initial capital as important determinants of self-employment survival. Bates (1990) provides some of first evidence on the probability of surviving in business for a sample of male entrepreneurs in the US and finds that those who possess greater business acumen, labour market skills, and capital, are more likely to survive ceteris paribus. ${ }^{1}$

Failure to address entrepreneurial success and self-employment survival could cast doubts on the efficiency of government programmes designed to facilitate individuals' entry into selfemployment. $^{2}$ The design and implementation of such programmes is informed by numerous empirical studies that examine mostly the factors affecting individuals' decision to become selfemployed, with relatively little information on the factors that determine entrepreneurial success and survival. High self-employment exit rates may be viewed as evidence of poor matches between entrepreneurial availability and skill requirements and can be costly, not only for the self-employed themselves but also for third parties, including banks, customers and governmental and private financial institutions. Understanding the determinants of self-employment survival could allow for a more complete response by policy makers who view entrepreneurship as the key to job creation and prosperity. 
In this paper, we provide additional empirical evidence regarding the factors that determine self-employment duration in Britain, paying particular attention to non-pecuniary aspects of selfemployment and self-reported job satisfaction variables. Although recent empirical work on the determinants of self-employment entry acknowledges the importance of job satisfaction for individuals' choice between salaried work and self-employment, the small number of studies examining self-employment survival focus exclusively on the role of standard economic and demographic variables. Generally, there is very little direct evidence on the correlation between self-reported satisfaction measures and self-employment duration. This is in sharp contrast to the empirical literature on labour turnover and mobility, where a growing number of studies examine the role of job satisfaction and non-pecuniary aspects of a job as strong predictors of quits [see for example, Akerlof et al (1988) and Clark et al (1998)]. More recently, Clark (2001), using employment spell data from the BHPS (omitting self-employment spells), finds that overall job satisfaction is indeed a powerful predictor of separations and quits, even after controlling for wages, demographic and other job variables. Interestingly, Clark (2001) also finds that job security and pay are the two job attributes most valued by workers.

Based on self-employment spell data from the BHPS, our results are generally consistent with the findings of previous studies as far as standard demographic and job variables are concerned. In particular, our results confirm the importance of assets and previous labour market status as important determinants of self-employment duration. Differences in survival rates across gender and different types of self-employment are also evident. However, we also find that job satisfaction and non-pecuniary characteristics of self-employment are strong predictors of selfemployment exit. Furthermore, when overall job satisfaction is broken down to five domain satisfaction variables, we find that satisfaction with pay, satisfaction with job security and satisfaction with work initiative emerge as the most important determinants of self-employment exit. This suggests that these three aspects of self-employment are the most valued by the selfemployed themselves. Similar findings emerge when estimating competing risk survival models, 
where exit probabilities to alternative destination states are compared. In general, the results of competing risks models lend support to the view that for many workers, self-employment is indeed a stepping stone to paid employment. Thus, the present paper contributes not only to increasing our general understanding of the determinants of self-employment survival, but also to a growing literature on the role of job satisfaction as a powerful predictor of quits and labour turnover, a rather novel aspect of the self-employment survival literature.

The paper is set out as follows: In section II, we describe the data and present some preliminary results based on non-parametric duration models. In section III, we present the results of single risk and competing risks proportional hazard models. In section IV, we conclude.

\section{Data and Preliminary Results}

Our data are from Waves 1 to 8 (1991 to 1998) of the British Household Panel Survey (BHPS), a nationally representative sample of some 5,500 households and 10,000 individuals interviewed annually every fall since 1991. The BHPS is a rich data set providing information not only on a wide range of personal, household, and labour market characteristics, but also on lifetime job histories. Children in the households are interviewed separately once they reach the age of sixteen, and if any member of a household splits to form a new household, then all adult members of both the original and new households are interviewed annually. By such means, the survey remains broadly representative of the British populace over time.

We restrict our samples to include individuals who are between the ages of 18 and 64 for men and 18 and 60 for women. Individuals for whom information on the main variables of interest is not available are excluded from the sample (see Table 1: Note - all Figures and Tables are set out in Appendix B).

By combining information contained in the BHPS spell data files with employment status information collected at each wave, we construct a complete self-employment history for each individual in the sample. Our final sample consists of 1,436 self-employment spells that could be 
matched to individual interview data after cases with missing data and cases with inconsistencies have been removed. ${ }^{3}$

In this sample, $170(11.83 \%)$ individuals have multiple spells and $1266(88.17 \%)$ have a single spell for the period 1991-1998. Treating self-employment duration as a continuous variable, the data shows that the mean self-employment duration for males is 67.87 months (5.65 years) whereas the mean duration for females is 50.08 months (4.17 years). The corresponding median figures are 35 months (2.91 years) and 24 months (2 years) respectively.

Non-parametric survival analysis techniques allow us to examine the probability of an individual leaving the self-employment state conditional on having survived in the origin state for the whole interval. Figure 1 (shows the survivor function for men and women using the KaplanMeier estimator (Kaplan and Meier, 1958). The Kaplan-Meier estimates suggest that the selfemployed are more likely to quit during the first 100 months (8.3 years) and that females have lower survival rates than do males. The male hazard rate rises quickly above 400 months (33.3 years), probably due to retirement, while the female rate is somewhat flatter. Looking at the survivor functions, 51 percent (70 percent) of males (females) were eliminated from selfemployment within 200 months (16 years). Gender differences in survival rates may reflect gender differences in the motives for and aspirations from self-employment, differences in labour market opportunities, and even differences in tastes for pecuniary vs. non-pecuniary aspects of entrepreneurship. ${ }^{4}$

Turning to the conditional probability of exiting to a new state, the survivor function, shown in Figure 2, illustrates how the exit probabilities vary with both time and the destination state under the competing risks assumption. We focus our attention to three main destinations states [notworking, including unemployment and family care (UNFC); wage employment (WE); and other self-employment (SE)], which account for 78.7 percent of all completed self-employment episodes. In order to assess whether non-working is distinctly different from unemployment, we also examine the survivor function for transitions from self-employment to unemployment (UN). The probability 
of moving from self-employment to unemployment/family care (UNFC) is markedly higher than the probability of moving to any other destination states until the $144^{\text {th }}$ month $\left(12^{\text {th }}\right.$ year), where the probabilities of moving to unemployment/family care and wage employment coincide. The most likely destination state is wage employment, followed by unemployment/family care and then by self-employment, supporting the view that self-employment is a stepping stone to paid employment. A possible explanation for this is that experience of self-employment unveils unobserved characteristics of the individual that increase the probability of finding a better match in the labour market.

Differences in the survivor functions between males and females are also confirmed by the Log-Rank test and Wilcoxon test for the equality of survivor functions (see Table 2). ${ }^{5}$ Both the LogRank test and the Wilcoxon test, reject the hypothesis of equality of the two survivor functions.

\section{Econometric Analysis: Proportional Hazard Models}

In this section, we examine the determinants of self-employment duration by estimating Cox proportional hazard models [Cox (1972)]. The Cox proportional hazard model is semi-parametric, in the sense that it involves an unspecified baseline hazard instead of requiring further distributional assumptions. This approach, standard in applied work, assumes that censoring does not provide any information about latent failure times beyond that available in the covariates [e.g., Katz and Meyer (1990)]. The Cox proportional hazard model is also convenient for dealing with right censoring.

We model self-employment duration using both single risk and competing risks models. The former refers to the probability of exit from self-employment, irrespective of the state of destination. Competing risks models are used to estimate the probability of exit to different states, namely paid employment, unemployment/family care, unemployment and self-employment. ${ }^{6}$ Under the assumption of independent hazards, the competing risks model allows us to test whether the explanatory variables have different effects on the propensity to leave self-employment depending on the state of destination. All explanatory variables are measured at the last available interview prior to the termination of the spell. ${ }^{7}$ 


\section{Results: Single Risk Proportional Hazard Model}

The results from estimating the single risk hazard model are shown in Table 3. ${ }^{8}$ As column 1 shows, males are more likely to survive in self-employment. Gender differences in self-employment survival could be attributed to differences in cultural attitudes towards entrepreneurship, risk-taking, and the availability and/or affordability of family services. Age has a significant and non-linear effect on self-employment survival. As Calvo and Wellisz (1980) suggest, age might be superior to labour market experience as both an indicator of the learning process and as an index of capital accumulation. Furthermore, Evans and Leighton (1989) claim that age may be a proxy for an individual's attitude towards risk, with mature-aged persons being less willing to bear the stress and risks associated with self-employment. Taylor (1999) includes two age dummies (aged < 30 and aged 30-49) and reports that male duration in self-employment is inversely related to age. Similar age effects are apparent for females, but the effect for both males and females disappears when the author desegregates his sample into voluntary and involuntary terminations. Consistent with the findings of Johansson (2001), our results show that there is a clear effect of age on the female risk of exiting self-employment, but such an effect is less pronounced for males.

Our results suggest that education is insignificantly related to business longevity. However, when the sample is decomposed by gender, the results show that higher education reduces females' hazard rate by 36 percent, whereas females with A-level qualifications have a 39 percent higher self-employment probability. Such findings are broadly consistent with previous empirical studies [e.g. Schiller and Crewson (1997), Taylor (1999) and Johansson (2001)].

Industrial affiliation plays a significant role, particularly for women. When overall survival dynamics are taken into account, those in manufacturing and finance industries have higher exit rates. When the sample is divided by gender, the effects seem to be more pronounced for women. ${ }^{9}$ This may be explained by the fact that these occupations are more likely to be suitable for contracting-out, thus offering more opportunities for self-employment. In addition, individuals employed in manufacturing and finance may find it less difficult to switch to wage employment as 
local demand conditions improve. On the other hand, our results may simply reflect the changing industrial structure of the British economy and the effects of the early 1990s recession.

Having a self-employed parent, although below unity, does not seem to significantly affect the probability of surviving. This is consistent with Bates (1990) who also reports that family business background has no effect on business longevity. Similarly, Schiller and Crewson (1997) are unable to identify any intergenerational links with respect to self-employment success for both men and women. Taylor (1999), however, finds some evidence of a correlation between having a self-employed parent and the exit rate from self-employment.

Other individual characteristics, important in influencing an individual's tenure in selfemployment, include marital status, number of children, and spouse's employment status. As the results in Table 3 suggest, being married is associated with a lower likelihood of leaving selfemployment. The effect of marriage is negatively and significantly associated with the hazard rate, and the effect seems to be more pronounced for men. As Borjas (1986) argues, if an entrepreneur's spouse also works in the business, then the allocation of labour is optimal since both will have the incentive of maximising family wealth. With the financial support of a spouse, especially if the spouse works, a married person may be more willing to continue in self-employment. The presence of dependent children is associated with a higher probability of leaving self-employment. Having to support a family might make an individual less inclined to take risks. On the other hand, it is possible that family support, both labour and financial, might make self-employment less demanding than it would be otherwise. Connely (1992) argues that the females' selection of employment strategies is influenced by family responsibilities. Blank (1989) claims that most women show a lower degree of attachment to paid employment rather than to self-employment because self-employed women may enjoy more flexible working schedules than wage and salary workers $^{10}$.

Another set of interesting covariates is the characteristics of the business, namely whether the self-employed individual hires employees, and/or whether specialises in the professional field. 
Entrepreneurs who create employment are significantly less likely to fail relative to own account workers. On the other hand, self-employed workers who run their own business exhibit a greater hazard of leaving self-employment relative to those self-employed workers who work on contract. Our results also suggest that those in professional occupations have a lower exit rate relative to those in non-professional occupations.

Based on two wealth measures - whether an individual received interest or dividend payments in the last 12 months exceeding $£ 1000$ or $£ 10000$ alongside self-employment income - the results confirm the liquidity constraints hypothesis. Individuals with greater self-employment income or wealth survive longer in self-employment. More specifically, interest and dividend income between $£ 1000$ and $£ 9999$ decreases the hazard associated with self-employment exit. ${ }^{11}$ Investment income more than $£ 10000$, although negatively associated with departure rates, does not seem to play a significant role in determining the probability of failure. This effect may be due to the non-linear relationship between wealth and the incidence of self-employment. As wealth increases, the importance of any initial constraint diminishes, though the impact in this regard is relatively more important at low levels of wealth. It might also be the case that as an individual's net wealth increases, the degree of risk aversion rises. Given the risky nature of self-employment, this may instigate a voluntary exit from self-employment or may deter continuance. Desegregation of the sample into males and females indicates that income and wealth are important only for men. Taylor (1999) includes a similar, but more aggregate measure of wealth (whether an individual received interest and dividend income exceeding £100) and reports a negative, but insignificant relationship with the hazard rate. Non-labour income, however, significantly reduces the male exit rates due to bankruptcy, whilst the wealth effect is negatively and insignificantly related to male voluntary terminations.

The 'recession-push' hypothesis of self-employment postulates that workers are 'pushed' into establishing their own businesses because they cannot find suitable paid employment opportunities. In contrast, the 'entrepreneurial pull' school of thought postulates that entrepreneurs 
are individuals with particular abilities and that self-knowledge of these abilities motivates them to seek an entrepreneurial pursuit. Whether individuals were 'pushed' or 'pulled' into selfemployment could determine the success, and therefore the duration, of the self-employment venture. Our results show that the effect of the national unemployment rate is not statistically significant. However, individuals who experienced unemployment prior to entering selfemployment have relatively lower survival rates, supporting the view that these individuals may have suffered some atrophy of their human capital and may be ill suited to self-employment challenges. These results are broadly consistent with the findings reported by Evans and Leighton (1989), Schiller and Crewson (1997), Carrasco (1999), Taylor (1999), Williams (2000) and Johansson (2001).

Previous business experience matters for men, but not for women. Schiller and Crewson (1997) show that the dominant predictors of entrepreneurial success are self-employment experience, which exerts a positive influence, unemployment experience, which exerts a negative influence on men only, and wage employment experience, which exerts a positive influence on women only. Taylor (1999) also finds previous self-employment experience to be an important determinant of survival. Previous paid employment experience emerges as another significant factor in the self-employment survival process, but this effect seems to be stronger for women than men. One possible explanation is that female workers may acquire new skills while self-employed, which facilitates their return to paid employment. Given, a previous paid employment experience, a spell in self-employment might lead to higher earnings and/or a higher probability of employment. In terms of Roy-type models analysed in Heckman and Sedlacek (1985), certain characteristics attract a higher return in self-employment than in salaried work, and therefore people with these characteristics will tend to self-select themselves into self-employment. In this context, time spent in self-employment is rewarded highly by future employers as it reveals unobserved characteristics of the individual. As a final remark concerning the role of previous labour market experience, the effects for males and females are likely to differ according to the extent to which levels and rates of 
return to investments in human capital differ across gender. In addition, there are important gender differences in the factors that affect the decision to enter self-employment, with personal characteristics such as household size, marital status, and the presence of dependent children, playing a greater role in the female decision [see Le (1999) for a review].

Our results show that workers who became self-employed after quitting their previous job in order to get a better job are more likely to exit self-employment, suggesting that perhaps these individuals were rather optimistic about the financial and non-financial prospects of their entrepreneurial venture. As Arabsheibani et al (2000) argue, those becoming self-employed are more liable to excess optimism and entrepreneurs seem to be quite often driven by wishful thinking. Our results show that for both men and women, such behaviour significantly increases the exit rate by 25 percent on average depending on the specification used.

Own account workers may be less confined to strict working schedules. We controlled for the ability of the individual to stagger his time over the day [flextime] and for the ability to work at home [work at home]. Our results suggest that survival in self-employment is not affected by workplace, but is affected by the times of day at which someone can work. For both 'all' and male respondents the risk of quitting is significantly reduced by the presence of flextime. For women, however, flextime significantly reduces the survival rate, ceteris paribus.

Finally, Table 3 shows that overall job satisfaction is a strong predictor of survival. The more satisfied is the individual, the less likely is he or she to terminate their current selfemployment spell. Desegregating the sample enables us to discern gender differences. The size and the significance of the coefficients reveal that if a man is generally satisfied with his job then the probability of his spell ending decreases by 26 per cent relative to those who are less satisfied with their job. The same is true for a generally satisfied female, although the significance level of the estimated coefficient cast some doubt s to the exact effect. The size and the significance levels of the overall satisfaction remain robust to changes in the model specification. 
In Table 4, we report the results of the proportional hazard model when overall satisfaction is substituted with a series of five domain job satisfaction variables. With respect to the five satisfaction components the most powerful variable is satisfaction with job security which is significant irrespective of gender. In other words, if we had to choose among the different job satisfaction categories in order to predict quits, then contentment with job security would allow us to make the most accurate prediction. Clark (2001) reports similar findings for full-time salaried employees. The significant effects of satisfaction with payment confirms the findings of the standard empirical labour literature which focuses only on labour income per se and not on the satisfaction associated with labour income.

To ensure the robustness of the results reported in Tables 3 and 4, a number of alternative specifications were tested. For example, given that the whole sample is created on the basis of full data availability for all the respondents and, hence, satisfaction variables are confined to those individuals for whom all seven measures are available. The log-likelihoods can therefore be compared across different models and specifications (see Table 5). The least negative log-likelihood implies that the corresponding regression is the regression with the greatest explanatory power. With respect to the satisfaction variables, the most powerful regressions are the ones in which individual components of satisfaction are included.

\section{Results: Competing Risks}

Table 6 reports the results of the competing risks models where differences in estimated coefficients across different destination states emerge. Starting with gender, males are more likely to exit selfemployment by becoming unemployed rather than economically inactive (out-of-the labour force). As in the single risk model, the age effect is associated with survival in a convex fashion and is significant for both the employment and non-employment hazards.

Higher education seems to either accelerate exit from self-employment to paid-employment or to sustain survival in non-employment. Self-employed individuals with A-levels, on the other hand, are more likely to enter a different self-employment state. With respect to industry, significant 
effects of manufacturing industry on paid employment, unemployment and non-employment likelihood arise, all acting to increase the hazard rate. In contrast, the retention rate hazard ratio of an individual working in the distribution industry is 20 percent higher than that of an individual not working in the distribution sector. Furthermore, the industrial dummies show that those working in the finance sector are more likely to go into paid-employment or non-employment.

In general, being married significantly reduces the probability of leaving self-employment. However, this effect appears to be less pronounced for wage employment, but stronger for the retention rate (reducing the hazard by 50 percent on average) and the unemployment outcome (reducing the hazard by 51 percent on average). In contrast, the presence of children exerts a significantly negative influence on self-employment survival, ceteris paribus. This effect pushes the self-employed out of labour force by 33 percent on average, but only by 20 percent for other destination states.

Differences in exit rates by occupation, firm size and type of work also emerge. The hazard ratio assigned to professional occupations depresses the retention rate by 67 percent, on average, and the exit to non-employment rate by 60 percent, relative to non-processionals. The significantly below unity hazard ratio on firm size in all competing risks indicates that the self-employed with employees tend to have longer self-employment spells than observationally equivalent workers who are own account workers. These effects appear to be reasonable, and they are more pronounced for non-employment hazard and less pronounced for self-employment hazard. If the self-employed worker runs his/her own business, he/she is more likely to end up in unemployment or out of labour force.

Wealth in the form of dividend and interest income increases survival rates for all exit destinations except self-employment. An individual in receipt of interest or dividend payments exceeding $£ 1000$ or $£ 10000$ is less likely to exit self-employment. The competing risks approach suggests that individuals belonging to both wealth categories are more likely to stay in selfemployment as wealth increases. Also, the effect is most pronounced for the unemployment 
destination state, followed by the paid employment outcome. Self-employment labour income appears to affect negatively and significantly the exit rate to unemployment and non-employment. However, the hazard ratio remains very close to 1 and therefore, probability-wise the effect of selfemployment income is very weak.

An increase of one percentage point in the national unemployment rate increases the exit rate to paid-employment by 14 percent on average. ${ }^{12}$ A one-percent increase in real GDP reduces the risk that an individual becomes unemployed by 11 percent on average, and increases the risk that the self-employed will stay in their current occupation by 10 percent on average. ${ }^{13}$

Our results also provide some insight into the role of experience for self-employment survival. Unemployment experience increases the probabilities of transition from self-employment to all states except self-employment. These probabilities are decreased if the individual enjoyed previous self-employment experience. The effect of wage employment experience is twofold. First, it plays a significant role in increasing the exit rate to paid-employment and second, it significantly increases the retention rate.

All hazards except non-employment, are positively and significantly linked to quitting voluntary the previous employment spell with the view of a better job as self-employed. In contrast, the effect of flexitime is negative and significant except in the case of self-employment to paid employment transitions. Even though the size of the corresponding hazard ratio is in line with flextime, flexplace does not exert any statistically significant influence.

The effect of job satisfaction is the same across all competing risks: the hazard ratios on overall job satisfaction in all the competing risks specifications indicate that those self-employed workers who are satisfied with their job tend to have much longer self-employment spells. The strongest result concerns the non-employment outcome that significantly reduces by more than 30 percent on average the probability of transition from self-employment to non-employment. This probability is marginally lower when paid employment and unemployment exit states are considered. 
Turning to the satisfaction components (see Table 7), the effect of job security again prevails, significantly deterring the self-employed from departing to unemployment. Higher security weighs down the paid employment hazard by more than 50 percent on average. It is worth pointing out that the hazard rate is substantially reduced by 50 percent more or less under all the specification adopted and, thus, indicates the catalytic role played by this domain. Finally, satisfaction with work itself does entail significant explanatory power although the hazard ratio implies by and large a positive association with self-employment survival. ${ }^{14}$

\section{Conclusion}

A large literature in labour economics has examined the factors that affect individuals' decision to become self-employed, and has informed the design and implementation of government programmes aiming to spur self-employment as the key to job creation and a way out of poverty. The success and efficiency of such programmes are best assessed by a rigorous analysis of selfemployment duration. Unfortunately, however, relatively few empirical studies have examined the factors that affect self-employment survival and exit, and only one such study focuses on British self-employment [see Taylor, (1999)]. In this paper, we extend Taylor's (1999) work to provide additional empirical evidence on the determinants of self-employment duration in Britain. In our analysis, we have paid particular attention to non-pecuniary aspects of self-employment and selfreported job satisfaction variables as important determinants of self-employment survival. Apart from the role of standard economic and demographic variables, our results confirm the importance of job satisfaction variables in explaining self-employment survival probabilities for both males and females. Our results suggest that specific aspects of self-employment, such as job security, using initiative, and satisfaction with pay, are those most valued by the self-employed. It would therefore appear that a complete response by policy makers, who believe that self-employment could alleviate poverty and generate jobs, requires a closer look not only at the determinants of self-employment duration, but also a closer look at how the self-employed themselves evaluate their jobs. 


\section{References}

Akerlof, G.A., Rose, A.K., and Yellen, J.L. (1988), 'Job Switching and Job Satisfaction in the U.S. Labor Market', Brookings Papers on Economic Activity, 2, 495-582.

Arabsheibani, G., De Meza, D., Maloney, J. and Pearson, B. (2000), 'And a Vision Appeared unto them of a Great Profit: Evidence of Self-deception among the Self-employed', Economics Letters, 64, 35-41.

Bates, T. (1990) 'Entrepreneur Human Capital Inputs and Small Business Longevity', Review of Economics and Statistics, 72, 551-59.

Blank, R. M. (1989), 'The Role of Part-time Work in Women's Labour Market Choices Over Time', American Economic Review, 79, 295-99.

Borjas, G. (1986), ‘The Self-employment Experience of Immigrants', Journal of Human Resources, 21, 485-505.

Calvo, G. A. and Wellisz, S. (1980), 'Technology, Entrepreneurs, and Firm Size', Quarterly Journal of Economics, 95, 663-77.

Carrasco, R. (1999), 'Transitions to and from Self-employment in Spain: An Empirical Analysis', Oxford Bulletin of Economic and Statistics, 61, 315-41.

Clain, S.H. (2000), 'Gender Differences in Full-Time Self-Employment', Journal of Economics and Business, 52, 499513.

Clark, A. (2001), 'What Really Matters in a Job? Hedonic Measurement Using Quit Data', Labour Economics, 8, 22342.

Clark, A., Georgellis, Y. and Sanfey, P. (1998), 'Job Satisfaction, Wage Changes and Quits: Evidence from Germany', Research in Labor Economics, 17, 95-121.

Connelly, R. (1992), 'Self-employment and Providing Child-Care', Demography, 29, 17-29.Constraints', Journal of Political Economy, 102, 53-75.

Cox, D. R. (1972), 'Regression Models and Life Tables', Journal of the Royal Statistical Society, 34, 187-220.

Evans, D. and Leighton, L. (1989), 'Some Empirical Aspects of Entrepreneurship', American Economic Review, 79, 519-35.

Halpin, B. (1997), 'Unified BHPS Work-Life Histories: Combining Multiple Sources Into a User-friendly Format', ESRC Research Centre for Micro-Social Change, University of Essex.

Heckman, J. and Sedlacek, G. (1985), 'Heterogeneity, Aggregation and Market Wage Functions: An Empirical Model of Self-selection in the Labour Market', Journal of Political Economy, 93, 1077-125.

Henley, A. (2004). 'House Price Shocks, Windfall Gains and Hours of Work: British Evidence.' Oxford Bulletin of Economics and Statistics. 66(4), pp.439-56.

Holtz-Eakin, D., Joulfaian, D., and Rosen, S. (1994) 'Sticking It Out: Entrepreneurial Survival and Liquidity

Hujer, R. and H. Schneider. (1989). 'The Analysis of Labor Market Mobility Using Panel Data.' European Economic Review 33(23), pp. 530-36.

Johansson, E. (2001) 'Determinants of Self-employment Duration-Evidence from Finish Micro-data', Mimeo, Swedish School of Economics and Business Administration.

Kaplan, E. L. and Meier, P. (1958), 'Nonparametric Estimation from Incomplete Observations', Journal of the American Statistical Association, 53, 457-81.

Katz, L. F. and Meyer, B. (1990), 'Unemployment Insurance, Recall Expectations, and Unemployment Outcomes', Quarterly Journal of Economics, 105, 973-1002.

Le, A. T. (1999), 'Empirical Studies of Self-employment', Journal of Economic Surveys, 13, 381-416.

Pissarides, C. A. and Weber, G. (1989), 'An Expenditure-Based Estimate of Britain's Black Economy', Journal of Public Economics, 39, 17-32.

Savage, I.R. (1956), 'Contributions to the Theory of Rank-Order Statistics- The Two Sample Approach', Annals of Mathematical Statistics, 27, 590-615.

Schiller, B. R. and Crewson, P. E. (1997), 'Entrepreneurial Origins: A Longitudinal Inquiry', Economic Inquiry, 35, 523-31.

Taylor, M. (1999), 'Survival of the Fittest? An Analysis of Self-employment Duration in Britain', Economic Journal, 109, C140-C155.

Wilcoxon, F. (1945), 'Individual Comparisons by Ranking Individuals', Biometrics, 1, 80-3.

Williams D. R. (2000), 'Consequences of Self-employment for Women and Men in the US', Labour Economics, 7, 66587 


\section{Appendix A}

Definition of Self-Employment

We define individuals as self-employed according to the two questions relating to employment status in the BHPS: First, there is a self-reported employment status question vis. Are you an employee or self-employed?; second, there is a question relating to the respondent's current labour force status - vis. Please look at this card and tell me which best describes your current situation? (List: self-employed, in paid employment, unemployed, retired, family care, full-time student, long-term sick / disabled, on maternity leave, on a government training scheme). We exclude part-time workers by restricting our attention to those respondents who report themselves as working more than 30 hours per week and also those who report self-employment as a second job. ${ }^{15}$

The self-employed in our study are those individuals who report themselves as being an employer, working on their own account, or being self-employed within their own unincorporated business. Restricting our sample to males (females) aged between 18 and 64 (18 and 60) left us with 2,020 respondents satisfying these criteria. We then followed Henley (2004) in discarding those respondents for whom: (i) the real hourly wage (base year 1990) lays outside the range $£ 1$ to $£ 40$; and (ii) reported weekly hours of work have been top-coded to a value of 99 . We also discarded those respondents who gave inconsistent answers across questions and/or waves (e.g. reporting themselves as both employed and self-employed). 584 respondents were discarded through such means leaving us with 1,436 respondents for actual estimation. Given that this sub-sample consists of some $72 \%$ of our initial estimation pool, our results can be viewed as fairly representative of the population. ${ }^{16}$

\section{Construction of the Sample}

Our sample is constructed from two data sources: First, 'current status' information is derived from the core BHPS 'longitudinal' surveys for 1991-1998. These surveys contain data on lifetime job history, and thereby on selfemployment spell durations, in a continuous record from September 1991 to December 1998. Second, we created a Lifetime Job History File from retrospective lifetime employment histories collected at waves 2 (1992) and 8 (1998), and lifetime occupational histories, collected at waves 3 (1993) and 8 (1998). The latter file provides information on all self-employment spells started from the time the respondent left full-time education up to December 1998 as well as industry, occupation, employment status and reasons for spell termination, and thus enables the creation of employment and occupational histories from the labour market entry to the latest BHPS survey wave.

Both current status and retrospective data can be problematic. The former may be subject so-called 'seam' effects (see, Haplin, 1997). These arise because of measurement error in the current status information, such that a spell which overlaps two interviews is reported with different substantive information at each interview, making it appear to change at an unknown date between the two interviews, and also because of measurement error in the start date of the spell. An obvious disadvantage, with retrospective data, is that it suffers from respondent recall error. Such error is minimised in the BHPS which, in line with the suggestion by Hujer and Schneider (1989), interviews respondents twice. Moreover, the self-employment spells that occurred between 1991 and 1998 comprise over $80 \%$ of all selfemployment spells recorded by the Lifetime Job History File.

Having removed inconsistencies from both the BHPS Panel Data file (for example, as a result of seam effects) and from the Lifetime Job History File (for example, as a result of recall error), we then created a matched data file, dropping those observations we were unable to match or which suffered from missing data. ${ }^{17}$

Since we know the starting date of the self-employment spell and when this spell is completed or censored, spell information can be matched back to individual records at the separate waves using the core BHPS data set from 1991 to 1998. The resulting benefit is that, by confining analysis to spells ending after the 1991 (wave 1) date of interview, additional individual, household and labour market characteristics can be included as explanatory variables in the empirical analysis. On the other hand, we are restricted into considering only those spells terminating between 1991 and 1998. ${ }^{18}$ Nevertheless, we are able to obtain a rich data set with multiple observations per self-employment spell (a spell may span over two or more interview dates). 


\section{Endnotes}

${ }^{1}$ Although not focusing exclusively on self-employment survival, a number of studies highlight important factors that affect an individual's probability of remaining self-employed. See for example, Holtz-Eakin et al (1994), Schiller and Crewson (1997), and Carrasco (1999).

${ }^{2}$ In recent years OECD countries have experienced an increase in the number of self-employed workers and the number of government programmes designed to spur entrepreneurship. Examples of such programmes include the US Small Business Administration's loan program, the Unemployed Entrepreneurs Program in France, the Enterprise Allowance Scheme in Britain, and the Überbrückungsgeld (bridging allowance) and AGF (Labour Promotion Act) programs in Germany.

${ }^{3}$ For a description of how the sample was constructed see Appendix A. Technical details concerning job history information contained in the BHPS can also be found in Halpin (1997).

${ }^{4}$ Most empirical studies of self-employment are based on male samples, with only a small number of studies focusing on gender differences regarding the factors that affect self-employment entry [e.g. Clain (2000)]. Studies that look at gender differences in self-employment survival are even more sparse.

${ }^{5}$ Compared to the Log-Rank test, the Wilcoxon test assigns heavier weights to earlier failure times when the number at risk is higher. See Savage (1956) and Wilcoxon (1945) for a detailed description of the Log-Rank and Wilcoxon tests.

${ }^{6}$ Note that the probability of moving from one self-employment state to another self-employment state is termed the 'retention rate'.

${ }^{7}$ Definitions of all variables are set out in Table 1 (Appendix B).

${ }^{8}$ The estimated coefficients are interpreted in terms of relative risk, so that a coefficient greater than 1 implies a greater risk (hazard) of exiting self-employment whilst a coefficient less than 1 implies a reduced risk. For example, for a continuous variable, an estimated coefficient of 0.5 indicates that a one-unit increase in the explanatory variable reduces the conditional probability of leaving self-employment by 50 percent. On the other hand, a coefficient of 1.5 increases the same probability by 50 percent. For a dummy variable, the estimated coefficient shows the proportional difference between the hazard rates when the dummy variable takes value 1 and when it takes value 0 .

${ }^{9}$ The female participation in construction industry is very small, only seven spells.

${ }^{10}$ This is confirmed below by our finding that non-standard working schedules increase the female departure rate from self-employment.

${ }^{11}$ Housing equity was also tried but this has no significant effects and the receipt of dividend and interest payments was preferred on the basis of log-likelihood comparisons. Investment income might contain more information about the individual's economic condition since self-employment income is subject to underreporting (Pissarides and Weber, 1989).

${ }^{12}$ This depends on the specification and the model adopted, although the differences in hazard ratios across the different models and specifications are not dramatic.

${ }^{13}$ We also experimented with the inclusion of year dummies into our various single and competing risk models. The results from this process, available on request, indicated that our key conclusion were unaffected - almosr all of the variation in self-employment survival is accounted for by movements in labour market experience, job satisfaction (both overall and domains), income and certain aspects of self-employment. The year dummies did, however reveal a positive but diminishing association between hazard and time, suggesting that the self-employed experienced relatively higher exit rates in the earlier part of the 1990s. Indeed, the pattern of the coefficients on the estimated time indicators reflects the movements of self-employment in Britain - the increase in self-employment rates during the 1980s was temporarily halted during the recessionary years of the early 1990s. From 1993 onwards, however, the upward trend resumed, plateauing out by the end of the decade at approximately $12 \%$ of the workforce. The regressions also allude to an increasing survival rate of self-employment over the decade with the level of state-dependence (i.e. the percentage of the self-employed who were self-employed the previous year) at some 70-80 percent by the end of the decade.

${ }^{14}$ To further check the robustness of the results, we replicated the results in Tables 3-7 by excluding professional selfemployed and those who exited self-employment due to retirement in separate specifications. To account for the possible bias due to attrition, we also estimated the models by excluding spells lost due to attrition. In all of the alternative specifications the main results are largely unchanged. These results are available upon request.

${ }^{15}$ The BHPS does not collect complete information on overtime rates and so the hourly wage is defined as usual gross monthly labour income from self-employment divided by 4.33 times weekly hours. These latter are defined as usual paid weekly hours, plus weekly paid overtime hours such that unpaid overtime hours are excluded from the definition.

${ }^{16}$ Sample selection is not an issue. Focusing on full-time self-employed individuals is standard in the literature. In our data, part-time self-employed and those who report self-employment as a second job constitute less than 5\% of the total number of self-employed. Furthermore, there is very little reliable information on key variables (e.g. earnings) for this group (part-timers and second job) with many missing values.

${ }^{17}$ For example, an individual may be recorded as self-employed in 1995 in the Lifetime Employment History File, having perhaps recalled in 1998 their 1995 status incorrectly, but recorded as an employee in Wave 5 (1995) of the BHPS survey. Any spells that yielded conflicting and ambiguous information were dropped and respondents who did not have valid information on employment status and the associated characteristics were excluded from the sample. To 
avoid discarding useful information, meticulous reconciliation of the status and the associated characteristics has been carried out.

${ }^{18}$ Spells still in process in 1998 and spells by respondents who left the sample due to attrition are treated as censored. 


\section{Appendix B}

\section{Table 1: Variable Definitions}

\begin{tabular}{|c|c|}
\hline \multicolumn{2}{|l|}{ Demography } \\
\hline Male & Dummy variable: $1=$ Male \\
\hline Age & Age of the Respondent. \\
\hline Married & Dummy variable: $1=$ Married \\
\hline No of Children & Number of Children in the Household \\
\hline Parent Self-Employed & Dummy variable: $1=$ had a self-employed father or mother when aged 14 \\
\hline White & Dummy variable: $1=$ White \\
\hline \multicolumn{2}{|l|}{ Education } \\
\hline Higher & Dummy variable: 1 = University or Higher Degree or equivalent \\
\hline A levels & Dummy variable: 1 = Advanced Level university entrance-level qualification \\
\hline Olevels & Dummy variable: 1 = Ordinary Level qualification \\
\hline Other $Q F$ & Dummy variable: $1=$ other Vocational or Academic Qualification(s) \\
\hline \multicolumn{2}{|r|}{ 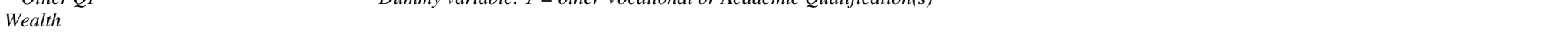 } \\
\hline$£ 1<$ Interest/Dividend Income $\leq £ 1,000$ & Dummy variable: $1=$ received more than $£ 1$ or less than $£ 1,000$ dividends or interest income \\
\hline Interest/Dividend Income $>£ 1,000$ & Dummy variable: $1=$ received more than $£ 1,000$ dividends or interest income \\
\hline Interest/Dividend Income .> £10,000 & Dummy variable: $1=$ received more than $£ 10,000$ dividends or interest income \\
\hline SE Earnings & Monthly Self-employment Labour Income \\
\hline \multicolumn{2}{|l|}{ Job Aspects } \\
\hline Overall Satisfaction & Job satisfaction on a scale 1 to 7 (1: not satisfied at all; 7: completely satisfied) \\
\hline Satisfaction with Payment & Satisfaction with pay on a scale 1 to 7 (1: not satisfied at all; 7 : completely satisfied) \\
\hline Satisfaction with Security & Satisfaction with security on a scale 1 to 7 (1: not satisfied at all; 7: completely satisfied) \\
\hline Satisfaction with Initiative & Satisfaction with initiative on a scale 1 to 7 (1: not satisfied at all; 7 : completely satisfied $)$ \\
\hline Satisfaction with Work Itself & Satisfaction with work itself on a scale 1 to 7 (1: not satisfied at all; 7: completely satisfied) \\
\hline Satisfaction with Hours & Satisfaction with hours on a scale 1 to 7 (1: not satisfied at all; 7: completely satisfied) \\
\hline Satisfaction with Flexitime & Dummy variable: 1 if job allows the respondent to stagger his/her work hours \\
\hline Satisfaction with Home Work & Dummy variable: 1 if respondent works mainly at homelfrom own home \\
\hline Quit for better job & Dummy variable: 1 if respondent quit previous spell because he/she thought he/she had better prospects in self-employment (voluntary termination) \\
\hline \multicolumn{2}{|r|}{ (2) } \\
\hline Self-employment & Dummy variable: 1 if respondent has experienced one or more periods of self-employment prior to his/her current spell, excluding current status \\
\hline Paid Employment & Dummy variable: 1 if respondent has experienced one or more periods of paid employment prior to his/her current spell, excluding current status \\
\hline Unemployment & Dummy variable: 1 if respondent has experienced one or more periods of unemployment prior to his/her current spell, excluding current status \\
\hline Has Employees & Dummy variable: 1 if respondent has any employees \\
\hline Professional SE & Dummy variable: 1 if respondent works in professional speciality occupations \\
\hline Type_own & Dummy variable: 1 if respondent runs his/her own business or professional practice \\
\hline Spouse Works & Dummy variable: 1 if spouse/partner is currently employed \\
\hline \multicolumn{2}{|l|}{ Industry } \\
\hline Manufacturing & Dummy variable: 1 if respondent works in light manufacturing industry \\
\hline Construction & Dummy variable: 1 if respondent works in the construction industry \\
\hline Distribution & Dummy variable: 1 if respondent works in the distribution, catering industries \\
\hline Finance & Dummy variable: 1 if respondent works in the banking, finance, insurance, business services and leasing industry \\
\hline Unemployment Rate & National Unemployment Rate \\
\hline \multicolumn{2}{|l|}{ Region } \\
\hline S.East & Dummy variable: 1 if resp. resides in South East \\
\hline S. West/ Anglia & Dummy variable: 1 if resp. resides in South West or East Anglia \\
\hline North & Dummy variable: 1 if resp. resides in the North \\
\hline Wales & Dummy variable: 1 if resp. resides in Wales \\
\hline Scotland & Dummy variable: 1 if resp. resides in Scotland \\
\hline
\end{tabular}


Table 2: Test For Equality Between Male and Female Survival Functions (See Endnote 5)

\begin{tabular}{|c|c|c|c|c|c|}
\hline & \multicolumn{2}{|c|}{ Log-Rank Test } & \multicolumn{3}{|c|}{ Wilcoxon Test } \\
\hline & $\begin{array}{l}\text { Events } \\
\text { Observed }\end{array}$ & $\begin{array}{l}\text { Events } \\
\text { Expected }\end{array}$ & $\begin{array}{l}\text { Events } \\
\text { Observed }\end{array}$ & $\begin{array}{l}\text { Events } \\
\text { Expected }\end{array}$ & $\begin{array}{l}\text { Sum of } \\
\text { Ranks }\end{array}$ \\
\hline Females & 207 & 153.57 & 207 & 153.57 & 46804 \\
\hline Males & 408 & 461.43 & 408 & 461.43 & -46804 \\
\hline \multirow[t]{2}{*}{ Total } & 615 & 615.00 & 615 & 615.00 & 0 \\
\hline & \multicolumn{2}{|c|}{$\begin{array}{c}\chi^{2}(1)=25.20 \\
\operatorname{Pr}>\chi^{2}(1)=0.000\end{array}$} & \multicolumn{3}{|c|}{$\begin{array}{c}\chi^{2}(1)=25.20 \\
\operatorname{Pr}>\chi^{2}(1)=0.000\end{array}$} \\
\hline
\end{tabular}


Table 3: Proportional Hazard Model - Single Risk (See Endnote 8)

\begin{tabular}{|c|c|c|c|}
\hline & All & Males & Females \\
\hline \multicolumn{4}{|l|}{ Demography } \\
\hline Male & $0.725(3.17)$ & - & - \\
\hline White & $1.575(2.33)$ & $1.825(2.57)$ & $1.220(0.53)$ \\
\hline Age & $0.955(2.24)$ & $0.973(1.13)$ & $0.929(2.36)$ \\
\hline $\mathrm{Age}^{2}$ & $1.078(3.02)$ & $1.055(1.83)$ & $1.120(2.09)$ \\
\hline Parent self-employed & $0.893(1.12)$ & $0.907(0.76)$ & $0.871(0.78)$ \\
\hline Married & $0.743(2.68)$ & $0.692(2.72)$ & $0.711(1.53)$ \\
\hline Number of children & $1.152(3.36)$ & $1.129(2.23)$ & $1.278(3.17)$ \\
\hline \multicolumn{4}{|l|}{ Education } \\
\hline Higher & $0.928(0.61)$ & $1.218(0.56)$ & $0.639(1.91)$ \\
\hline A-Levels & $1.165(1.02)$ & $1.395(1.86)$ & $0.759(0.89)$ \\
\hline O-Levels & $0.948(0.40)$ & $0.962(0.23)$ & $0.909(0.41)$ \\
\hline Other qualification & $0.918(0.57)$ & $1.001(0.31)$ & $0.718(1.31)$ \\
\hline \multicolumn{4}{|l|}{ Region } \\
\hline South East & $1.108(1.17)$ & $1.082(0.72)$ & $1.314(1.71)$ \\
\hline South West/East Anglia & $1.066(0.58)$ & $1.181(1.93)$ & $0.924(0.47)$ \\
\hline North & $1.134(1.97)$ & $1.002(1.82)$ & $1.207(1.09)$ \\
\hline Wales & $0.701(1.52)$ & $0.688(1.25)$ & $0.859(0.38)$ \\
\hline Scotland & $1.168(0.22)$ & $1.040(0.21)$ & $0.761(0.99)$ \\
\hline \multicolumn{4}{|l|}{ Industry } \\
\hline Manufacturing & $1.443(2.25)$ & $1.221(0.89)$ & $1.719(2.14)$ \\
\hline Construction & $1.226(1.59)$ & $0.961(0.28)$ & - \\
\hline Distribution & $1.093(0.73)$ & $0.806(1.32)$ & $1.274(1.88)$ \\
\hline Finance & $1.535(3.16)$ & $1.199(1.06)$ & $1.719(2.26)$ \\
\hline \multicolumn{4}{|l|}{ Self-employment type } \\
\hline Has employees & $0.487(5.75)$ & $0.582(3.52)$ & $0.353(4.39)$ \\
\hline Professional & $0.715(1.70)$ & $0.662(1.78)$ & $1.145(0.35)$ \\
\hline Type-Owner & $1.549(4.87)$ & $1.505(3.59)$ & $1.897(4.02)$ \\
\hline Spouse works & $0.929(2.05)$ & $0.871(2.01)$ & $1.245(0.99)$ \\
\hline Gross Pay & $0.997(3.66)$ & $0.998(3.96)$ & $0.995(0.83)$ \\
\hline \multicolumn{4}{|c|}{ Income from interest/dividends } \\
\hline$>£ 1000$ & $0.730(2.92)$ & $0.681(2.81)$ & $0.847(0.89)$ \\
\hline$>£ 10000$ & $0.777(1.60)$ & $0.761(1.49)$ & $0.828(0.58)$ \\
\hline Job satisfaction & $0.949(2.73)$ & $0.930(2.91)$ & $0.889(0.22)$ \\
\hline Flextime & $0.852(1.76)$ & $0.600(4.23)$ & $1.416(2.24)$ \\
\hline Work at home & $0.950(0.56)$ & $0.979(0.18)$ & $0.806(1.35)$ \\
\hline Previously self-employed & $0.858(2.72)$ & $0.808(2.95)$ & $0.917(2.42)$ \\
\hline Previously full-time employee & $1.434(2.36)$ & $1.235(1.14)$ & $1.820(2.06)$ \\
\hline Previously unemployed & $1.382(3.68)$ & $1.447(3.40)$ & $1.216(1.21)$ \\
\hline Quit for better job & $1.390(7.64)$ & $1.217(6.92)$ & $1.176(3.73)$ \\
\hline Unemployment rate & $1.024(1.22)$ & $1.024(1.05)$ & $1.028(0.66)$ \\
\hline No of spells & 1436 & 1007 & 429 \\
\hline No of failures & 615 & 408 & 207 \\
\hline Percent censored & 57.17 & 59.48 & 51.75 \\
\hline Log-Likelihood & -3758.55 & -2356.92 & -981.70 \\
\hline Log-Likelihood & -3762.1 & -2359.5 & -980.1 \\
\hline
\end{tabular}


Table 4: Proportional Hazard Model - Single Risk

Satisfaction with Specific Job Aspects

\begin{tabular}{lcccccc}
\hline & \multicolumn{3}{c}{ All } & \multicolumn{2}{c}{ Males } & \multicolumn{2}{c}{ Females } \\
\hline & Coef & T-Stat & Coef & T-Stat & Coef & T-Stat \\
Satisfaction with pay & 0.992 & 1.98 & 0.880 & 2.24 & 0.970 & 0.61 \\
Satisfaction with job security & 0.849 & 6.85 & 0.818 & 5.36 & 0.869 & 2.98 \\
Satisfaction with initiative & 0.797 & 2.13 & 0.816 & 2.03 & 0.881 & 1.98 \\
Satisfaction with work itself & 0.977 & 0.64 & 0.932 & 1.49 & 0.911 & 1.15 \\
Satisfaction with hours & 1.059 & 1.98 & 1.092 & 2.44 & 1.008 & 0.14 \\
\hline No of spells & \multicolumn{2}{c}{1436} & & 1007 & 429 \\
No offailures & \multicolumn{2}{c}{615} & & 408 & 207 \\
Percent censored & 57.17 & 59.48 & 51.75 \\
Log-Likelihood & -3458.5 & -2133.6 & -900.88 \\
\hline \hline
\end{tabular}

Other controls as in Table 3 except 'Job Satisfaction' which is replaced by the five domain job satisfaction variables above. 
Table 5: Binary vs. Survival Models

\begin{tabular}{|c|c|c|c|c|c|c|}
\hline & \multicolumn{3}{|c|}{$\begin{array}{c}\text { Probit Estimates } \\
\text { Stayers }(1) \text { vs Leavers }(0)\end{array}$} & \multicolumn{3}{|c|}{$\begin{array}{c}\text { Cox Proportional Hazard } \\
\text { Estimates }\end{array}$} \\
\hline & All & Men & Women & All & Men & Women \\
\hline Overall & 0.058 & 0.090 & 0.008 & 0.923 & 0.877 & 0.996 \\
\hline Satisfaction & $(2.47)$ & (3.19) & $(0.18)$ & $(-2.81)$ & $(-3.81)$ & $(-0.08)$ \\
\hline Constant & $\begin{array}{l}-0.132 \\
(1.01)\end{array}$ & $\begin{array}{l}-0.243 \\
(1.56)\end{array}$ & $\begin{array}{l}0.001 \\
(0.01)\end{array}$ & - & - & - \\
\hline Log-likelihood & -977.4 & -674.6 & -297.08 & -3953.2 & -2495.9 & -1051.0 \\
\hline Overall & 0.049 & 0.074 & 0.004 & 0.948 & 0.915 & 0.9864 \\
\hline Satisfaction & $(2.07)$ & $(2.58)$ & $(0.10)$ & $(-7.87)$ & $(-2.56)$ & $(-0.27)$ \\
\hline Labour Income & $\begin{array}{l}0.015 \\
(4.33)\end{array}$ & $\begin{array}{l}0.017 \\
(4.25)\end{array}$ & $\begin{array}{l}0.018 \\
(0.36)\end{array}$ & $\begin{array}{l}0.987 \\
(-6.29)\end{array}$ & $\begin{array}{c}0.977 \\
(-5.47)\end{array}$ & $\begin{array}{l}0.9999 \\
(-0.96)\end{array}$ \\
\hline Has Employees & $\begin{array}{l}0.465 \\
(5.55)\end{array}$ & $\begin{array}{l}0.399 \\
(3.95)\end{array}$ & $\begin{array}{l}0.646 \\
(4.28)\end{array}$ & $\begin{array}{c}0.473 \\
(-6.61)\end{array}$ & $\begin{array}{c}0.513 \\
(-4.85)\end{array}$ & $\begin{array}{l}0.3637 \\
(-4.95)\end{array}$ \\
\hline Constant & $\begin{array}{r}-0.335 \\
(2.46)\end{array}$ & $\begin{array}{r}-0.443 \\
(2.74) \\
\end{array}$ & $\begin{array}{c}-0.140 \\
(0.56)\end{array}$ & - & - & - \\
\hline Log-likelihood & -944.0 & -651.47 & -286.8 & -3888.19 & -2455.0 & -1031.5 \\
\hline$L R \chi^{2}[3]$ & 73.06 & 56.60 & 20.54 & 137.59 & 95.46 & 39.03 \\
\hline $\operatorname{Prob}>\chi^{2}$ & 0.00 & 0.00 & 0.00 & 0.00 & 0.00 & 0.00 \\
\hline \multicolumn{7}{|l|}{ Satisfaction with: } \\
\hline Total Pay & $\begin{array}{l}0.050 \\
(2.13)\end{array}$ & $\begin{array}{l}0.064 \\
(2.22)\end{array}$ & $\begin{array}{l}0.020 \\
(0.48)\end{array}$ & $\begin{array}{l}0.939 \\
(-2.18)\end{array}$ & $\begin{array}{c}0.932 \\
(-1.98)\end{array}$ & $\begin{array}{l}0.953 \\
(-1.01)\end{array}$ \\
\hline Job Security & $\begin{array}{l}0.129 \\
(6.51)\end{array}$ & $\begin{array}{l}0.130 \\
(5.54)\end{array}$ & $\begin{array}{l}0.141 \\
(3.74)\end{array}$ & $\begin{array}{l}0.808 \\
(-9.07)\end{array}$ & $\begin{array}{c}0.787 \\
(-8.30)\end{array}$ & $\begin{array}{c}0.843 \\
(-4.19)\end{array}$ \\
\hline Initiative & $\begin{array}{l}0.199 \\
(3.24)\end{array}$ & $\begin{array}{l}-.512 \\
(2.64)\end{array}$ & $\begin{array}{l}0.521 \\
(2.01)\end{array}$ & $\begin{array}{l}0.739 \\
(-2.57)\end{array}$ & $\begin{array}{c}0.803 \\
(-3.08)\end{array}$ & $\begin{array}{c}0.872 \\
(-2.02)\end{array}$ \\
\hline Work Itself & $\begin{array}{l}-0.081 \\
(2.67)\end{array}$ & $\begin{array}{l}-0.070 \\
(1.88)\end{array}$ & $\begin{array}{l}-0.101 \\
(1.91)\end{array}$ & $\begin{array}{l}1.119 \\
(2.84)\end{array}$ & $\begin{array}{l}1.118 \\
(2.30)\end{array}$ & $\begin{array}{l}1.107 \\
(1.53)\end{array}$ \\
\hline Hours of Work & $\begin{array}{l}-0.037 \\
(1.53)\end{array}$ & $\begin{array}{l}-0.046 \\
(1.88)\end{array}$ & $\begin{array}{l}-0.006 \\
(0.13)\end{array}$ & $\begin{array}{l}1.088 \\
(2.78)\end{array}$ & $\begin{array}{l}1.090 \\
(2.32)\end{array}$ & $\begin{array}{l}1.068 \\
(1.29)\end{array}$ \\
\hline Constant & $\begin{array}{l}-0.019 \\
(0.11)\end{array}$ & $\begin{array}{l}-0.037 \\
(0.17)\end{array}$ & $\begin{array}{l}-0.142 \\
(0.46)\end{array}$ & - & - & - \\
\hline Log-likelihood & -946.5 & -654.3 & -286.2 & -3896.6 & -2453.9 & -1036.5 \\
\hline$L R \chi^{2}(5)$ & 68.03 & 50.82 & 21.79 & 120.69 & 97.70 & 28.94 \\
\hline Prob $>\chi^{2}$ & 0.00 & 0.00 & 0.00 & 0.00 & 0.00 & 0.00 \\
\hline \multicolumn{7}{|l|}{ Satisfaction with } \\
\hline Total Pay & $\begin{array}{l}0.034 \\
(1.42)\end{array}$ & $\begin{array}{l}0.044 \\
(1.48)\end{array}$ & $\begin{array}{l}0.004 \\
(1.10)\end{array}$ & $\begin{array}{c}0.976 \\
(-0.83)\end{array}$ & $\begin{array}{c}0.967 \\
(-0.91)\end{array}$ & $\begin{array}{c}0.989 \\
(-0.22)\end{array}$ \\
\hline Job Security & $\begin{array}{l}0.112 \\
(5.54)\end{array}$ & $\begin{array}{l}0.115 \\
(4.80)\end{array}$ & $\begin{array}{l}0.120 \\
(3.12)\end{array}$ & $\begin{array}{c}0.834 \\
(-7.68)\end{array}$ & $\begin{array}{c}0.811 \\
(-7.22)\end{array}$ & $\begin{array}{c}0.866 \\
(-3.45)\end{array}$ \\
\hline Initiative & $\begin{array}{l}0.509 \\
(3.21)\end{array}$ & $\begin{array}{l}0.512 \\
(2.99)\end{array}$ & $\begin{array}{l}0.515 \\
(3.87)\end{array}$ & $\begin{array}{c}0.731 \\
(-2.68)\end{array}$ & $\begin{array}{c}0.839 \\
(-2.98)\end{array}$ & $\begin{array}{l}0.885 \\
(1.96)\end{array}$ \\
\hline Work Itself & $\begin{array}{l}-0.074 \\
(2.42)\end{array}$ & $\begin{array}{l}-0.067 \\
(1.77)\end{array}$ & $\begin{array}{l}-0.094 \\
(1.75)\end{array}$ & $\begin{array}{l}1.094 \\
(2.31)\end{array}$ & $\begin{array}{l}1.107 \\
(2.12)\end{array}$ & $\begin{array}{l}1.062 \\
(0.93)\end{array}$ \\
\hline Hours of Work & $\begin{array}{l}-0.021 \\
(0.86)\end{array}$ & $\begin{array}{l}-0.033 \\
(1.120\end{array}$ & $\begin{array}{l}0.015 \\
(0.34)\end{array}$ & $\begin{array}{l}1.061 \\
(1.97)\end{array}$ & $\begin{array}{l}1.066 \\
(1.74)\end{array}$ & $\begin{array}{l}1.040 \\
(0.76)\end{array}$ \\
\hline Labour Income & $\begin{array}{l}0.037 \\
(3.63)\end{array}$ & $\begin{array}{l}0.028 \\
(3.54)\end{array}$ & $\begin{array}{l}0.048 \\
(0.01)\end{array}$ & $\begin{array}{c}0.987 \\
(-5.34)\end{array}$ & $\begin{array}{c}0.985 \\
(-4.67)\end{array}$ & $\begin{array}{c}0.978 \\
(-0.61)\end{array}$ \\
\hline Has Employees & $\begin{array}{l}0.392 \\
(4.58)\end{array}$ & $\begin{array}{l}0.339 \\
(2.75)\end{array}$ & $\begin{array}{l}0.558 \\
(3.58)\end{array}$ & $\begin{array}{c}0.540 \\
(-5.37)\end{array}$ & $\begin{array}{c}0.585 \\
(-3.83)\end{array}$ & $\begin{array}{c}0.412 \\
(-4.28)\end{array}$ \\
\hline Constant & $\begin{array}{l}-0.188 \\
(1.06) \\
\end{array}$ & $\begin{array}{r}-0.200 \\
(0.92) \\
\end{array}$ & $\begin{array}{r}-0.237 \\
(0.76) \\
\end{array}$ & - & - & - \\
\hline Log-likelihood & -923.2 & -637.6 & -279.4 & -3853.2 & -2425.7 & -1024.0 \\
\hline$L R \chi^{2}[7]$ & 114.49 & 84.24 & 35.25 & 207.54 & 154.07 & 53.97 \\
\hline $\operatorname{Prob}>\chi^{2}$ & 0.00 & 0.00 & 0.00 & 0.00 & 0.00 & 0.00 \\
\hline Sample Size & 1436 & 1007 & 429 & 1436 & 1007 & 429 \\
\hline
\end{tabular}

Robust t-ratios in parentheses. 
Table 6: Proportional Hazard Model - Competing Risks

\begin{tabular}{|c|c|c|c|c|c|c|c|c|}
\hline & \multicolumn{2}{|c|}{$S E \rightarrow S E$} & \multicolumn{2}{|c|}{$S E \rightarrow P E$} & \multicolumn{2}{|c|}{$S E \rightarrow U N$} & \multicolumn{2}{|c|}{$S E \rightarrow O L F$} \\
\hline & Coeff. & t-ratio & Coeff. & t-ratio & Coeff. & t-ratio & Coeff. & $t$-ratio \\
\hline \multicolumn{9}{|l|}{ Demography } \\
\hline Male & 1.175 & 1.53 & 0.850 & 0.80 & 1.224 & 2.58 & 0.495 & 3.84 \\
\hline White & 1.325 & 2.15 & 1.137 & 0.39 & 1.433 & 1.01 & 1.497 & 1.33 \\
\hline Age & 1.005 & 0.07 & 0.882 & 1.98 & 0.979 & 0.37 & 0.985 & 1.94 \\
\hline$A g e^{2}$ & 0.989 & 0.12 & 1.035 & 2.09 & 1.045 & 0.57 & 0.932 & 0.51 \\
\hline Parent Self-employed & 1.149 & 1.15 & 1.113 & 1.33 & 1.176 & 1.65 & 1.316 & 0.90 \\
\hline Married & 0.685 & 2.40 & 0.852 & 0.78 & 0.854 & 2.66 & 0.799 & 1.24 \\
\hline No of Children & 1.184 & 1.84 & 1.171 & 1.94 & 1.215 & 2.70 & 1.301 & 2.49 \\
\hline \multicolumn{9}{|l|}{ Education } \\
\hline Higher & 1.772 & 1.73 & 1.318 & 2.07 & 0.807 & -0.78 & 0.603 & 2.36 \\
\hline A-Levels & 1.906 & 1.93 & 1.597 & 1.59 & 0.810 & -0.55 & 0.752 & 1.03 \\
\hline O-Levels & 1.149 & 0.38 & 1.111 & 0.37 & 0.994 & -0.02 & 0.948 & 0.27 \\
\hline Other & 1.292 & 0.60 & 1.176 & 0.49 & 1.044 & 0.13 & 0.696 & 1.39 \\
\hline \multicolumn{9}{|l|}{ Region } \\
\hline S. East & 1.192 & 0.53 & 1.098 & 0.52 & 1.506 & 1.87 & 1.301 & 1.66 \\
\hline S.West/E. Anglia & 1.294 & 0.70 & 1.185 & 1.74 & 1.211 & 0.72 & 1.128 & 0.61 \\
\hline North & 1.280 & 0.70 & 1.093 & 0.44 & 1.265 & 0.95 & 1.373 & 1.80 \\
\hline Wales & 0.380 & 0.92 & 0.414 & 1.88 & 0.467 & 1.13 & 0.605 & 1.13 \\
\hline Scotland & 1.012 & 0.35 & 1.503 & 1.91 & 0.855 & 0.45 & 0.749 & 1.08 \\
\hline \multicolumn{9}{|l|}{ Industry } \\
\hline Manufacturing & 2.003 & 1.59 & 1.841 & 2.07 & 3.340 & 3.09 & 1.917 & 2.11 \\
\hline Construction & 1.322 & 0.87 & 0.996 & 0.02 & 1.413 & 1.28 & 1.171 & 1.71 \\
\hline Distribution & 0.826 & 0.51 & 0.834 & 0.73 & 1.129 & 1.19 & 1.329 & 1.35 \\
\hline Finance & 1.047 & 0.13 & 1.892 & 2.64 & 1.517 & 1.04 & 1.908 & 2.47 \\
\hline Has Employees & 0.563 & 1.85 & 0.465 & 3.30 & 0.459 & 2.66 & 0.354 & 4.55 \\
\hline Professional Self-employed & 0.320 & 1.79 & 0.995 & 0.02 & 0.415 & 1.40 & 0.423 & 1.77 \\
\hline Type of Self-emp: Owner & 1.310 & 1.11 & 1.252 & 1.26 & 1.127 & 3.44 & 1.138 & 4.14 \\
\hline Spouse works & 1.110 & 0.38 & 1.307 & 1.38 & 0.847 & 1.26 & 1.077 & 0.43 \\
\hline Gross pay & 0.987 & 0.18 & 0.999 & 0.56 & 0.994 & 2.90 & 0.987 & 3.62 \\
\hline \multicolumn{9}{|c|}{ Income from interest and dividends } \\
\hline$>£ 1,000 \&<£ 10,000$ & 0.708 & 1.23 & 0.512 & 3.06 & 0.417 & 3.04 & 0.650 & 2.20 \\
\hline$\geq £ 1,000$ & 0.735 & 0.66 & 0.347 & 3.03 & 0.279 & 2.38 & 0.345 & 2.42 \\
\hline \multicolumn{9}{|l|}{ Other } \\
\hline Job satisfaction & 0.946 & 1.78 & 0.903 & 1.95 & 0.865 & 2.08 & 0.888 & 2.24 \\
\hline Flextime & 0.653 & 1.75 & 0.838 & 1.02 & 0.494 & 3.11 & 0.740 & 1.85 \\
\hline Work at home & 0.989 & 0.05 & 0.893 & 0.64 & 0.908 & 0.46 & 0.895 & 0.70 \\
\hline $\begin{array}{l}\text { Voluntary Termination of } \\
\text { Previous spell }\end{array}$ & 1.490 & 4.25 & 1.263 & 2.86 & 1.687 & 2.35 & 1.678 & 1.76 \\
\hline Self-employed & 0.888 & 2.50 & 0.990 & 2.06 & 0.573 & 2.65 & 0.720 & 2.08 \\
\hline Full-time employee & 1.832 & 1.39 & 1.515 & 1.46 & 1.001 & 0.25 & 1.211 & 0.79 \\
\hline Unemployed & 1.551 & 1.95 & 1.682 & 3.11 & 2.357 & 3.99 & 1.747 & 3.53 \\
\hline Unemployment Rate & 1.061 & 1.15 & 1.124 & 2.74 & 1.061 & 1.30 & 1.029 & 0.80 \\
\hline No of spells & \multicolumn{2}{|c|}{1220} & \multicolumn{2}{|c|}{1220} & \multicolumn{2}{|c|}{1220} & \multicolumn{2}{|c|}{1305} \\
\hline No of failures & \multicolumn{2}{|c|}{100} & \multicolumn{2}{|c|}{179} & \multicolumn{2}{|c|}{120} & \multicolumn{2}{|c|}{205} \\
\hline$\%$ Censored & \multicolumn{2}{|c|}{91.80} & \multicolumn{2}{|c|}{85.33} & & & & \\
\hline L-likelihood & & & & & & & & \\
\hline$L R \chi^{2}$ & & & & & & & & \\
\hline
\end{tabular}


Table 7: Proportional Hazard Model - Competing Risks

Satisfaction with Job Aspects

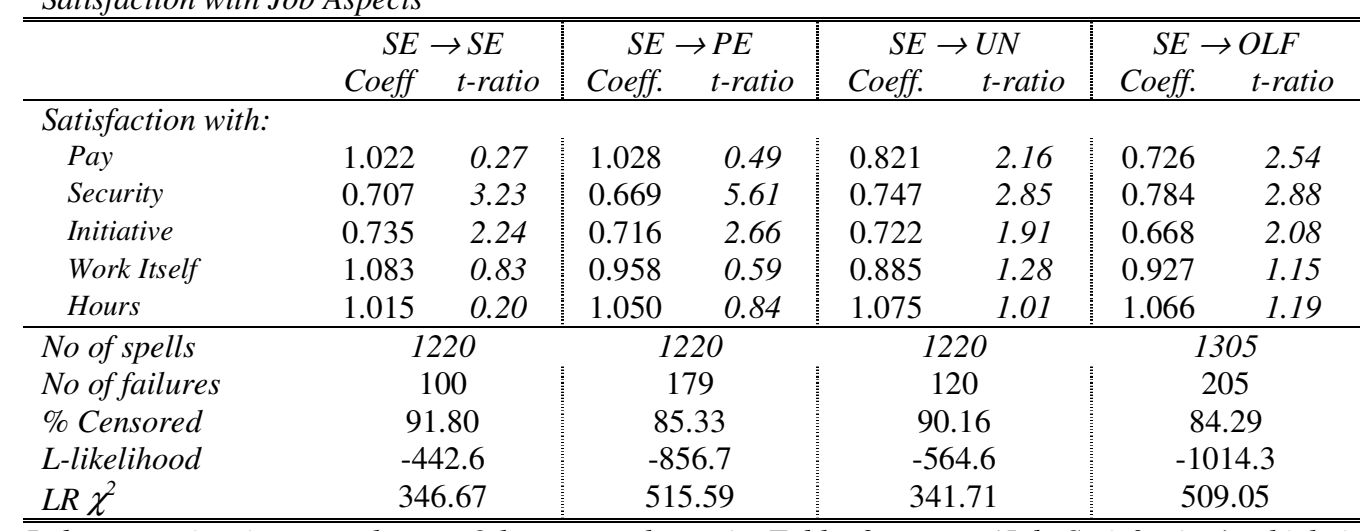

Robust t-ratios in parentheses. Other controls as in Table 3 except 'Job Satisfaction' which is replaced by the five domain job satisfaction variables above. 


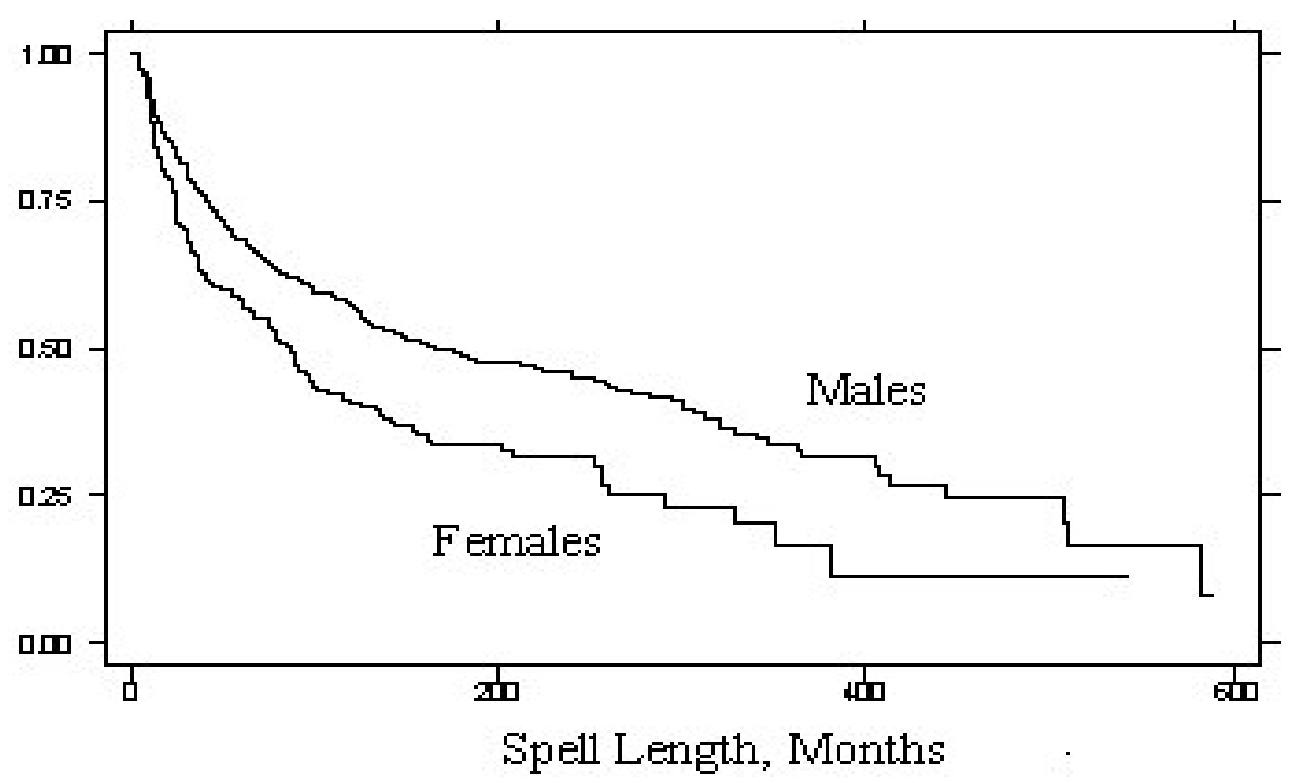

Figure 1: Survivor Function (All Individuals))

Kaplan-Meier (1958) estimated probability of individual leaving self-employment in period $t$ conditional on having been self-employed previous in period $t-1$. 


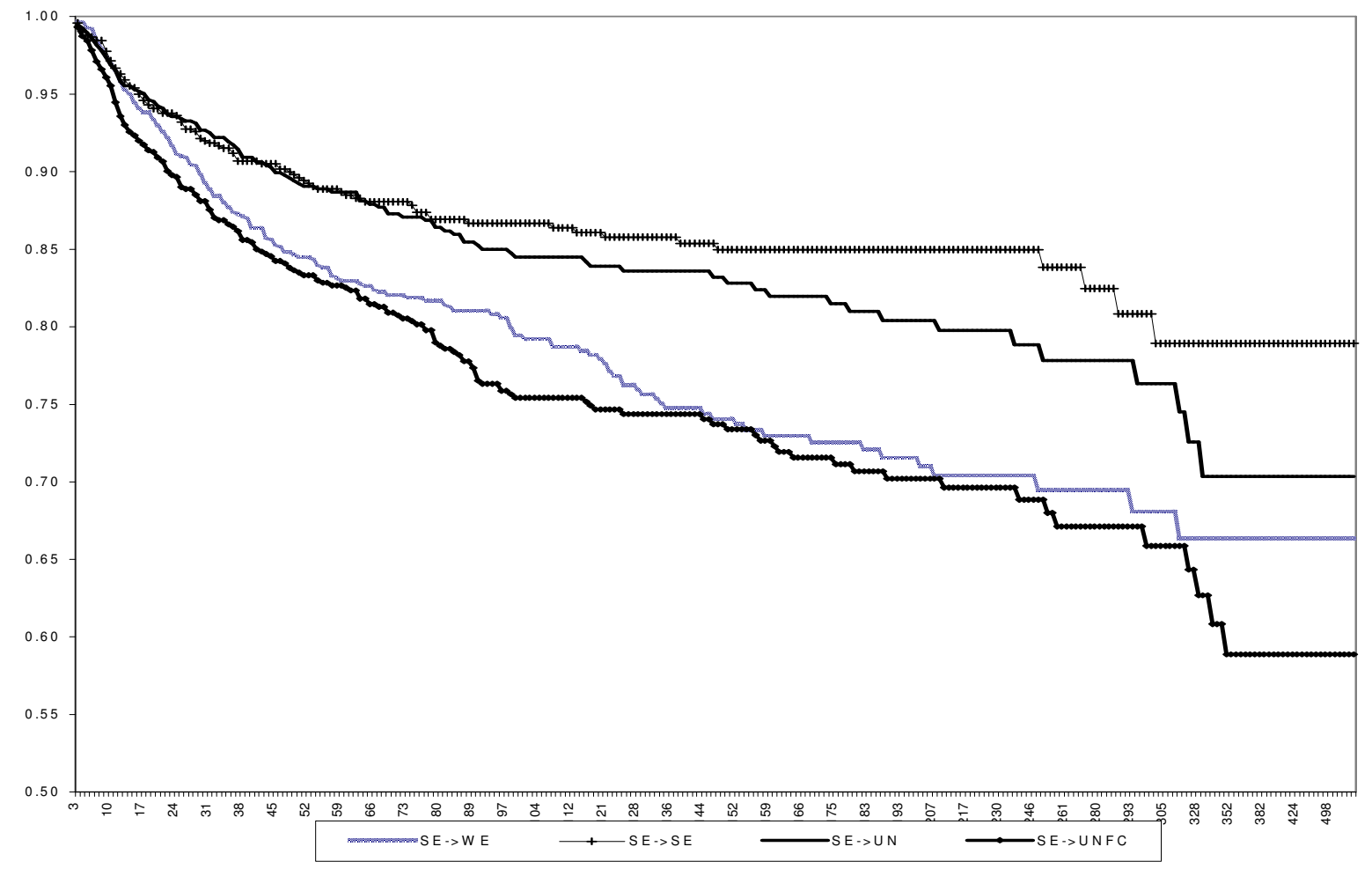

Figure 2: Survivor Function by Destination State (All Individuals)

Survivor function illustrating the conditional probability of exiting to one of three main destinations states vis. notworking, including unemployment and family care (UNFC); wage employment (WE); and other self-employment (SE)], which account. 